\title{
COMPARATIVE LIFE CYCLE ANALYSIS OF HYBRID AND CONVENTIONAL DRIVE VEHICLES IN VARIOUS DRIVING CONDITIONS
}

\author{
Emilia M. Szumska \\ Department of Automotive Engineering and Transport, Kielce University of Technology, Kielce, Poland \\ *E-mail of corresponding author: eszumska@tu.kielce.pl
}

\begin{abstract}
Resume
Growing environmental concern prompts vehicle users to search for cleaner and ecological transport modes. Many consumers and organizations have decided to replace conventional diesel or gasoline powered vehicles with alternative drive or alternative-powered vehicles. Operating conditions may have a heavy influence on the operating parameters of vehicles, such as: airpollution emission, energy consumption and fuel consumption. This paper presents a comparative analysis of the life cycle of conventional and hybrid drive vehicles in various driving conditions. The presented LCA results show that replacing a conventional diesel or gasoline vehicle with a hybrid electric drive vehicle results in approximately $40 \%$ lower total lifetime air-pollutant emissions than those of conventional drive vehicles in urban driving conditions.
\end{abstract}

Available online: https://doi.org/10.26552/com.C.2021.4.D34-D41

\section{Article info}

Received 17 September 2020

Accepted 25 October 2020

Online 8 July 2021

\section{Keywords:}

hybrid electric vehicles, Life Cycle Assessment, emission

ISSN 1335-4205 (print version)

ISSN 2585-7878 (online version)

\section{Introduction}

Transport activities bring substantial socioeconomic benefits and support increasing demands for passengers and cargo mobility, but on the other hand, have an unfavorable impact on environmental systems. Among all economic activities, transport is recognized to be one of the major sources of the greenhouse gases emissions. In 2017 the greenhouse gases emissions emitted by transport were $25 \%$ of the total GHGs emissions of the European Union economy (Figure 1). Road transport generated the highest air-pollutant emissions of all the transport modes (Figure 2).

The authors of study [3] distinguished transport impacts within three categories:

- direct impacts - represent the immediate consequences of transport activities for the environment. They are easily identified and have direct harmful effects, such as: noise and carbon monoxide emissions;

- indirect impacts - are defined as the secondary (or tertiary) effects of transport activities on environmental systems. They are more difficult to establish and have more serious consequences than the direct impacts; for example, particulate matters that are indirectly associated with human respiratory and cardiovascular problems;

- cumulative impacts - are the additive, multiplicative or synergetic consequences of transport activities, including the varied effects of direct and indirect impacts on an ecosystem, which are often unpredictable, such as climate change.

The negative effect of the road transport manifests itself through: climatic changes caused by the greenhouse gas emissions and loss of biological diversity by occupation of land by newly build roads and technical infrastructure vehicles. The growing network of roads has dramatically altered the landscape and can impact wildlife in a number of deleterious ways [4]. Pollution by harmful substances, caused by movement of motor vehicles, as well as light and noise pollution from roads, can be detrimental to wild animals [5-6]. Many studies, focused on sustainable transport efficiency, consider air-pollutants as an undesirable output, the examples of which are found in papers [7-8].

The impact of road transport is especially noticeable in cities. According to results presented in papers [9-11] traffic and congestion can increase air-pollutant emission by as much as $80 \%$. Local emissions of air and noise pollutants caused by movement of motor vehicles negatively influence human health. According to WHO studies, transport-generated urban air pollution causes: cardiovascular and pulmonary diseases, ischemic heart disease, cancers, asthma and strokes. Outdoor air pollution alone is responsible for 4.2 million deaths annually [12-13]. To reduce air pollutants many cities have decided to adopt activities to support sustainable development. These actions entail reduction of parking 


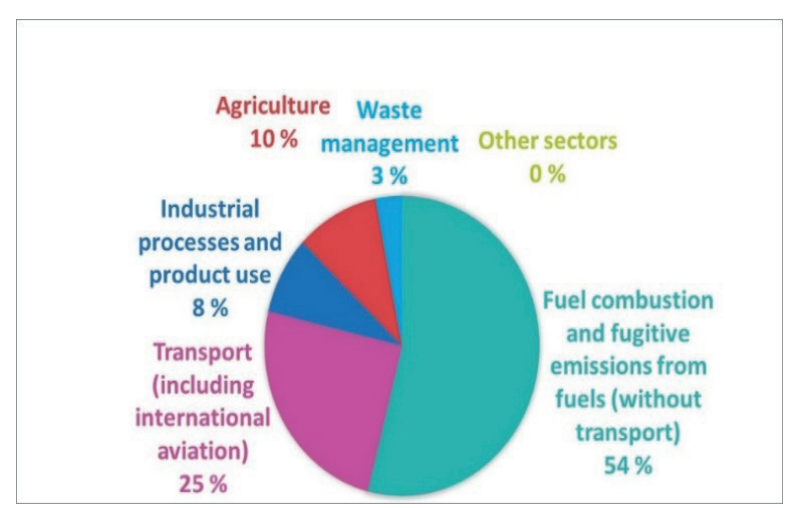

Figure 1 Greenhouse gases emissions, by source sector in EU-28 in 2017 [1]

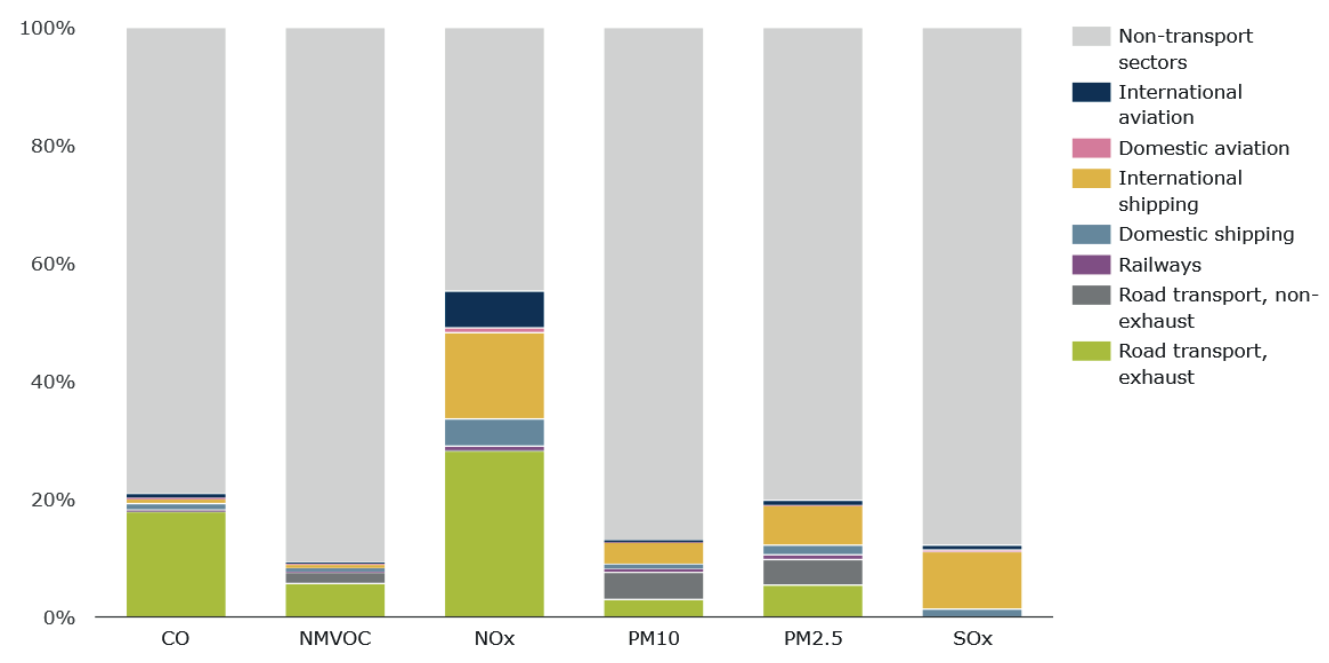

Figure 2 Contribution of the transport sector to total emissions of the main air-pollutants [2]

zones, increasing parking fees in the city center, site greening, encouraging the use of public transport and creating new cycle paths - these being but a select few of such actions in cities [14].

To reduce this negative aspect of driving, car manufacturers have begun producing vehicles that are more environmentally friendly. At present, the largest majority of cars are equipped with systems ensuring low emissions. Some of the solutions that have been developed include engine improvements (such as variable charge motion in-cylinder, cylinder deactivation and GDI - gasoline direct injection), exhaust gas recirculation, turbo chargers, three-way converters and particulate matter filters. In addition, the number of low-emission automobiles on the roads is growing. Vehicles equipped with alternative drives (electric, hybrid) and powered by alternative fuels (CNG, LPG, biofuels) are a commonplace sight. Operating conditions may heavily influence vehicle operating parameters, such as air-polluting emissions, energy and fuel consumption. The aim of this paper is to provide a comparative air-pollutant analysis of vehicles equipped with conventional drives and those equipped with hybrid drives. Therefore, the Life Cycle Assessment method was used to examine the lifetime air-pollutant emissions for the hybrid and conventional drives vehicles in various driving conditions.

\section{LCA - Life Cycle Assessment}

The Life Cycle Assessment (LCA) is focused on estimation and assessment of environmental impacts consequences on individual stages of a vehicle life cycle. Those include e consumption of the raw materials and energy and their emission of harmful gases and substances, starting with the vehicle production phase through the production of materials to the assembly phase and to e usage of a vehicle along with the necessary f production of fuel or electrical energy and the level of fuel consumption and terminating with the end of the life cycle and the attendant costs of recycling and utilization. The LCA is commonly used to assess different vehicle technologies from various points in their life cycle. It should be noted that economic criteria are not taken into account in the LCA method [15]. Studies [16-17] identified, quantified and assessed the environmental impacts by the entire $\mathrm{LC}$ of vehicles equipped with alternative and conventional drives using the LCA methodology. Many studies have been devoted to the Life Cycle Assessment for city buses equipped with various types of propulsion systems. Papers [18-19] present comparison analyses of lifetime vehicle emission values of the manufacture, use, maintenance and 


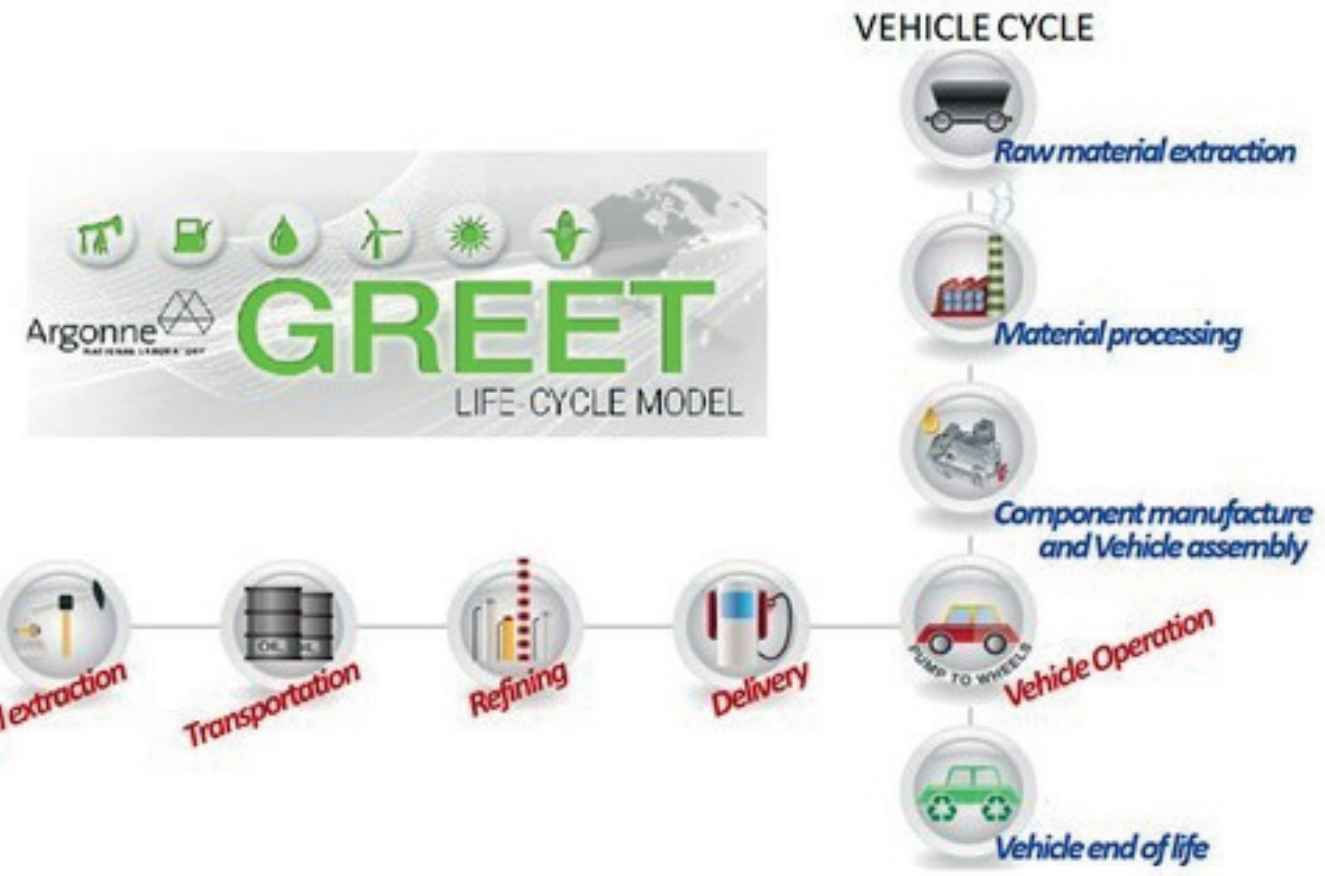

Figure 3 Scheme of the GREET software tool [26]

infrastructure phases of diesel, hybrid and battery electric buses.

The LCA method can be used to assess the environmental impacts of a specific vehicle component's life cycle. For example, papers [20-21] present the analyses of greenhouse gas emissions of every stage of the lithium-ion battery life-cycle. Studies [22-23] present the estimation of the environmental impacts of recycling during the vehicle's end-of-life.

The LCA results could be used for the estimation of Life Cycle Cost. Emissions values of harmful compounds assessed using the LCA method are presented in the form of costs. Therefore, the costs of emissions are the constituent element of the total life cycle costs of a vehicle. Examples are found in papers [24-25].

\section{Methodology}

The presented LCA analysis was carried out for passenger cars fitted with conventional power drives and hybrid electric power drives. The total mileage was assumed as $300000 \mathrm{~km}$ and the operation time was 10 years. The LCA analysis was conducted for three types of driving conditions: driving in urban conditions, driving in areas entirely outside the city and conditions where driving was done in a combination of urban and non-urban, in half of shares each (50-50).

The Life Cycle Assessment (LCA) was carried out using the GREET program (Greenhouse gases, RegulatedEmissions and Energy use in Transportation Model), developed by the Argonne National Laboratory
(ANL) as a part of a project ran by the US Department of Energy. The GREET program enables estimating the impact of individual phases of the life cycle of vehicles equipped with conventional and alternative propulsion systems on the natural environment. The program uses data provided by studies undertaken by the EPA (Environmental Protection Agency), an US Government agency dealing with the protection of human health and the environment [26]. The GREET provides the opportunity to estimate energy consumption and emissions of harmful compounds caused by production and distribution of fuel and by all the phases of a vehicle's life cycle. The program scheme is presented in Figure 3.

The model of a vehicle's life cycle includes the submodels: "the fuel cycle" and "the vehicle cycle". The fuel cycle includes raw material extraction, raw material transport, refining and purification, distribution and consumption of fuel during the vehicle operation. In the vehicle cycle model the following stages are identified: sourcing of raw materials, production and processing of raw materials, production of components, assembly of a vehicle , operation of a vehicle and its decommissioning. The results of calculations are:

- the amount of energy coming from the combustion of the fossil fuels (oil, gasoline, gas, coal) or from renewable sources (biomass, wind, solar rays, water);

- the level of greenhouse gas emissions $\left(\mathrm{CO}_{2}\right.$, $\mathrm{CH}_{4}, \mathrm{~N}_{2} \mathrm{O}$ ) of harmful compounds contained in the exhaust gases $\left(\mathrm{CO}, \mathrm{NO}_{\mathrm{x}}, \mathrm{PM}_{\mathrm{x}}, \mathrm{SO}_{\mathrm{x}}\right.$, aliphatic and aromatic hydrocarbons);

- water creation. 


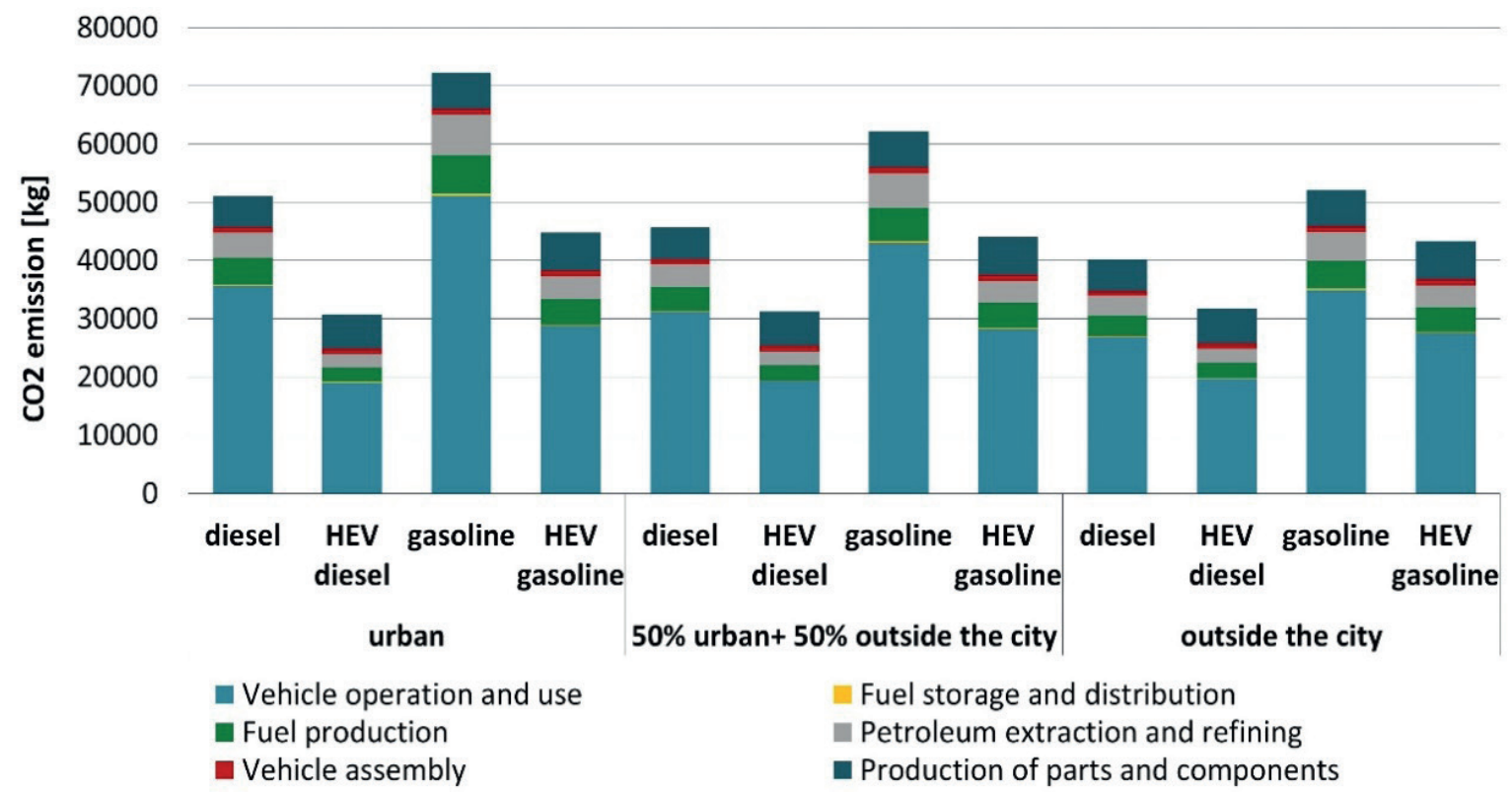

Figure $4 \mathrm{CO}_{2}$ emissions over the vehicle life cycle

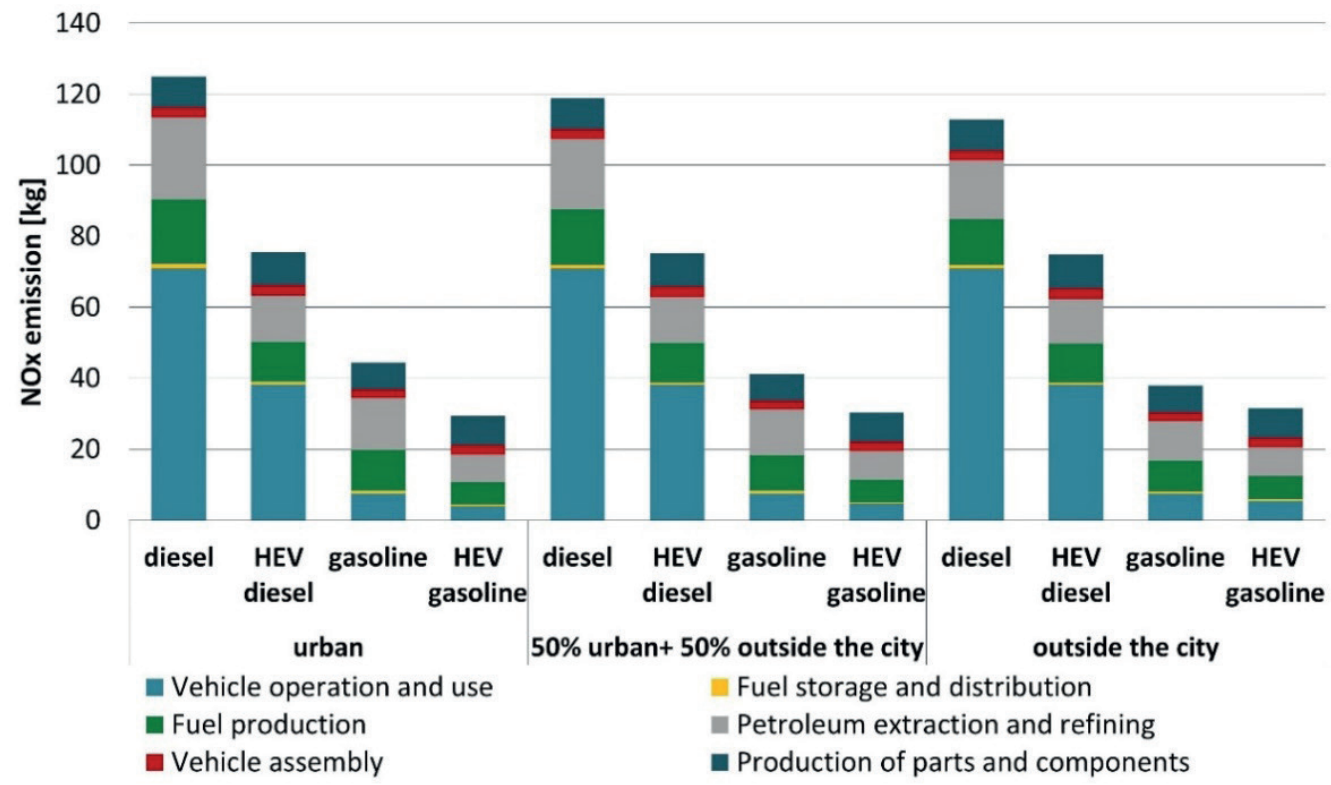

Figure $5 \mathrm{NO}_{x}$ emissions over the vehicle life cycle

\section{Results}

The LCA analysis provided shows the levels of emissions of carbon dioxide $\left(\mathrm{CO}_{2}\right)$, nitrogen oxides $\left(\mathrm{NO}_{\mathrm{x}}\right)$, particulate matter $\left(\mathrm{PM}_{\mathrm{x}}\right)$ and volatile organic compounds (VOC) for the environmental life cycle of the examined passenger cars. The life cycle of the vehicles selected for investigation is divided into the following phases: fuel production (petroleum extraction and refining, production of fuel, distribution and storage), production of a vehicle (production of parts and components and vehicle assembly) and the vehicle operation and use. Figure 4 shows the $\mathrm{CO}_{2}$ emission level of the above mentioned compounds for the life cycle of cars with conventional drives and cars with hybrid drives.

It can be seen that the vehicles equipped with gasoline engines demonstrate the highest level of the lifetime $\mathrm{CO}_{2}$ emission. For urban driving conditions the vehicles equipped with a hybrid drive show a level of life cycle carbon dioxide emissions approximately $40 \%$ lower than those of the conventional cars. For the combined driving conditions (urban and outside the urban area), the $\mathrm{CO}_{2}$ life cycle emissions emitted by the hybrids are $30 \%$ less than those of the conventional drive vehicles. In driving conditions outside the urban area, the cars equipped with gasoline- and diesel-powered engines exhibit $20 \%$ higher $\mathrm{CO}_{2}$ emissions than the hybrid vehicles.

The highest share in the lifetime $\mathrm{CO}_{2}$ emissions value falls on the phase of vehicle operation and use, approximately $70 \%$ of the total $\mathrm{CO}_{2}$ life cycle emissions. The nitrogen oxides $\left(\mathrm{NO}_{\mathrm{x}}\right)$ emissions 


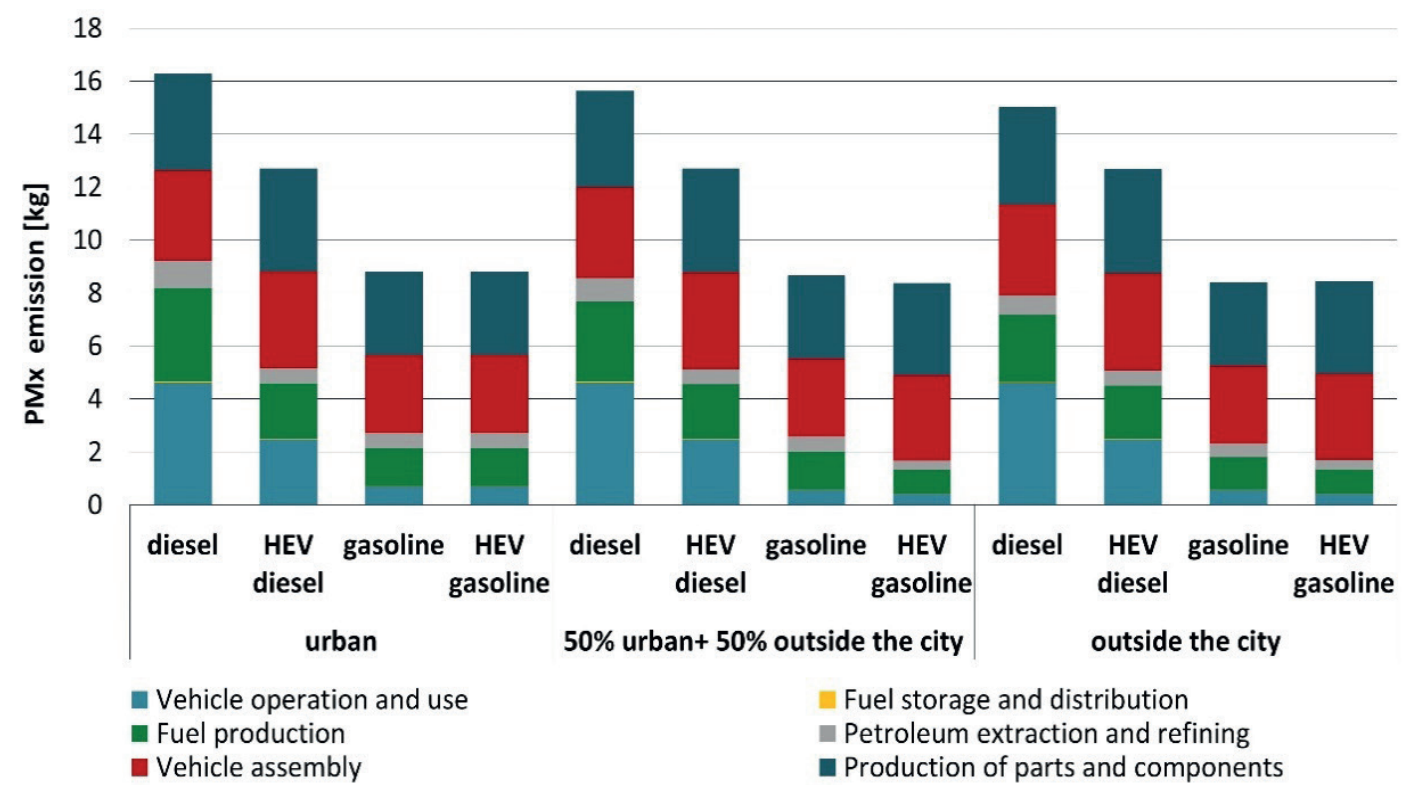

Figure $6 \mathrm{PM}_{x}$ emissions over the vehicle life cycle

120

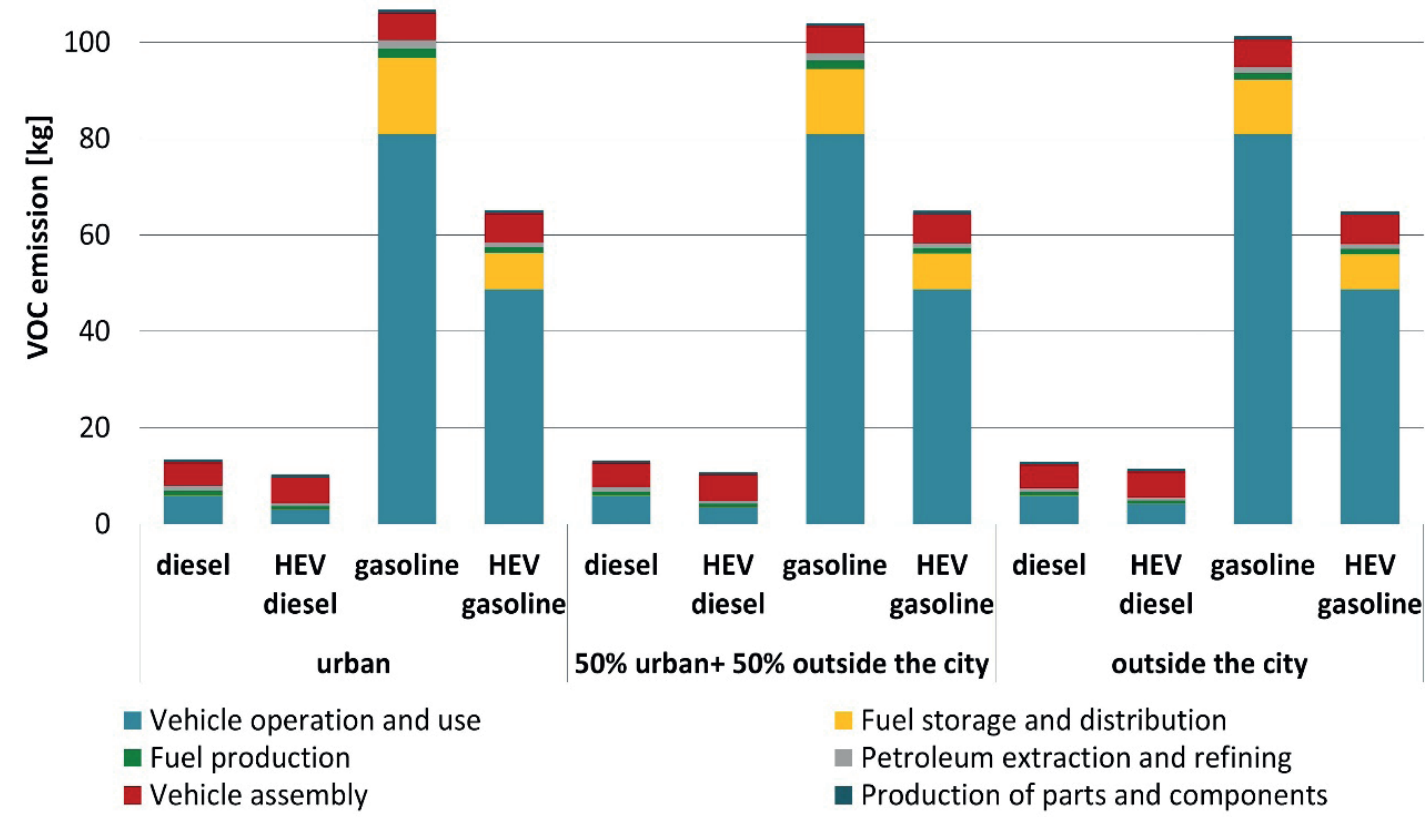

Figure 7 VOC emissions over the vehicle life cycle

levels for the life cycles of the analysed vehicles are presented in Figure 5.

The vehicle operation and use stage is the largest contributor to the life cycle $\mathrm{NO}_{\mathrm{x}}$ emissions for vehicles fitted with diesel engines, accounting for $51 \%-62 \%$ of total $\mathrm{NO}_{\mathrm{x}}$ emissions. It is found that for the examined driving conditions, the lifetime $\mathrm{NO}_{\mathrm{x}}$ emissions estimate by diesel hybrid is approximately $40 \%$ lower than those of conventional diesel car. In conditions both urban combined in-city and outside the urban area driving, the total life cycle $\mathrm{NO}_{\mathrm{x}}$ emissions emitted by gasoline hybrid car are approximately $30 \%$ less than those of the conventional gasoline vehicle. In conditions excluding city driving the difference is $17 \%$. The greatest share of the lifetime $\mathrm{NO}_{\mathrm{x}}$ emissions of vehicles fitted with gasoline engines falls on phases of production, distribution and storage of fuel, approximately $60 \%$ of the total. Figure 6 shows the level of particulate matter $\left(\mathrm{PM}_{\mathrm{x}}\right)$ emissions during the life cycles of the analysed vehicles.

The particulate matter emissions level for a hybrid diesel car are about $20 \%$ lower compared to a conventional diesel vehicle. The differences in $\mathrm{PM}_{\mathrm{x}}$ emissions emitted by hybrid and conventional vehicles equipped with a gasoline engine are negligible, at most $3 \%$. The largest part of lifetime particulates emissions falls on the phases related to the production of ae vehicle, that is to say, production 


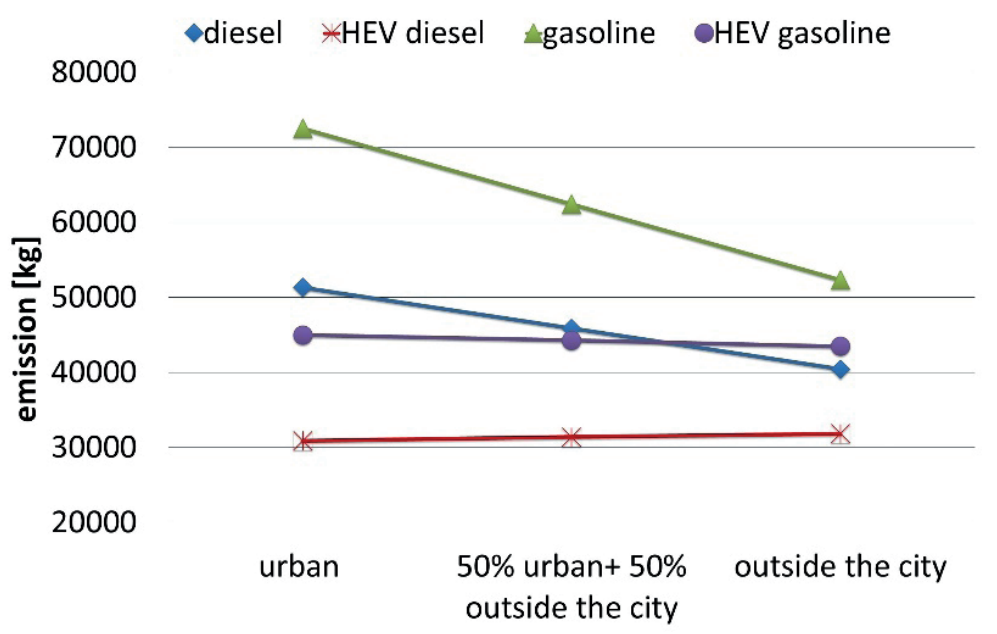

Figure 8 Air pollutant emissions over the vehicle life cycle

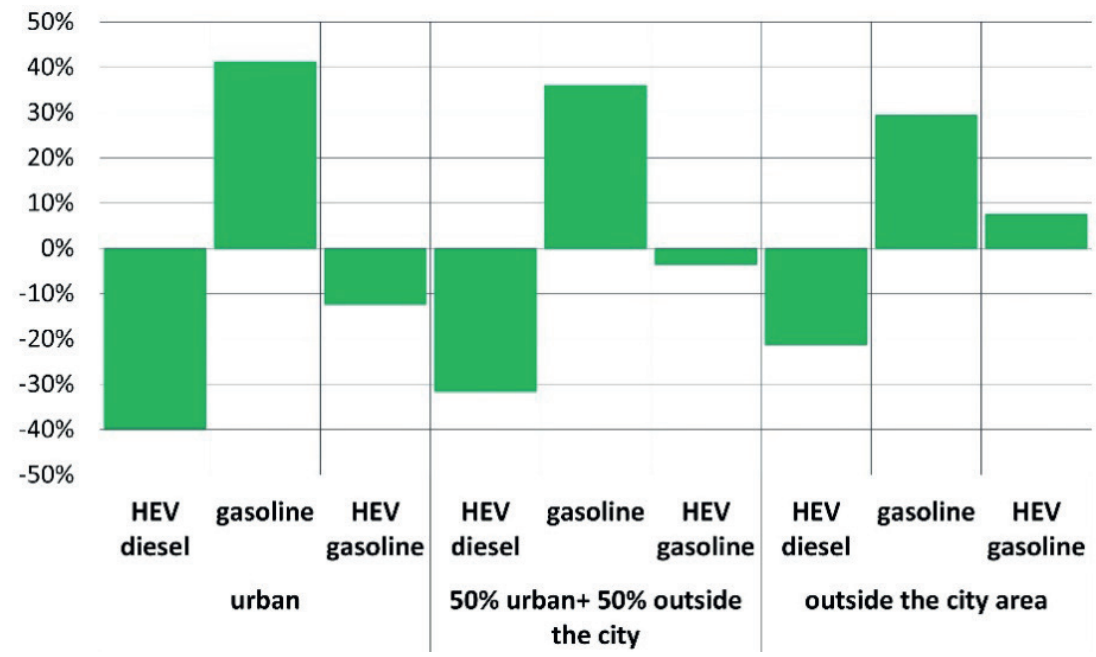

Figure 9 Percentage difference of lifetime air-pollutant emissions related to conventional diesel vehicle (diesel emission $=100 \%$ )
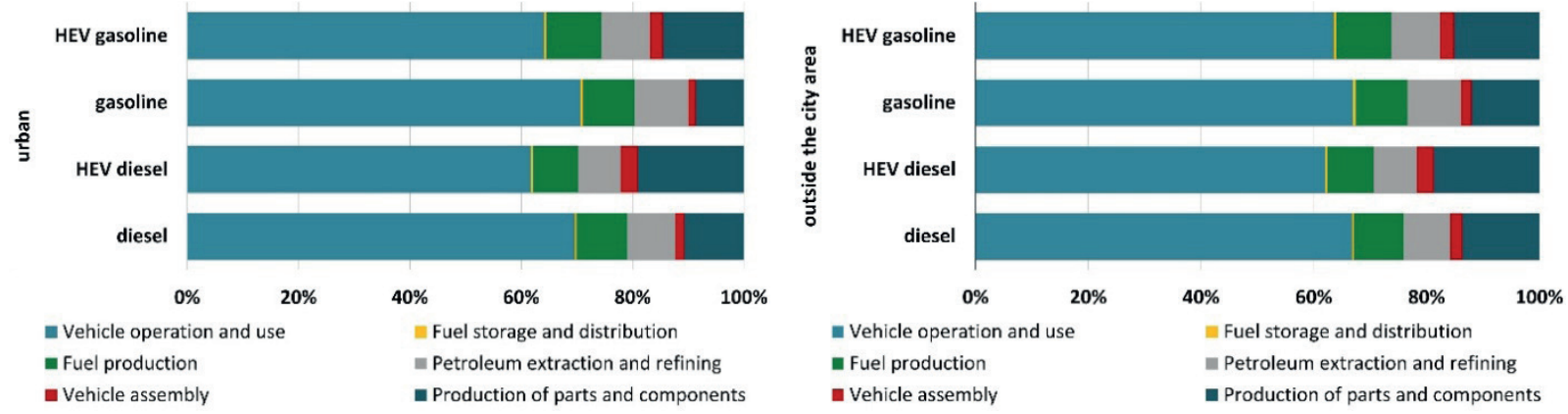

Figure 10 Percentage of lifetime air pollutant emissions during different life cycle stages

of parts and components and assembly of a vehicle. In addition, it can be seen that the high percentage of air pollutant emission emitted by diesel-powered cars, falls on the operation stage, accounting for $20 \%-30 \%$ of the total. The levels of volatile organic compounds (VOC) for the life cycles of the analysed vehicles are shown in Figure 7.

Volatile organic compounds contain aliphatic hydrocarbons (decane, octane, hexane), aromatic hydrocarbons (toluene, xylene, benzene), benzene alkyl derivatives, aldehydes, ketones, amines, alcohols, esters, terpenes and others. The highest share of the VOC life time emissions occurs in the vehicle operation stage. The vehicles fitted with gasoline-powered engines demonstrate higher VOC emissions values than the diesel-powered cars. Figure 8 shows values for air pollutant emissions during the life cycle stages of the examined vehicles.

In urban driving conditions, the vehicles equipped with hybrid drives have $40 \%$ lower life cycle air pollutant emissions than do the conventional cars (Figure 9). Smaller differences occur in driving condition outside 
the urban area, where the hybrids achieve approximately $20 \%$ lower air pollutant emissions in comparison to the conventional vehicles. Compared to the conventional vehicles fitted with a diesel-powered engine, in all the examined driving conditions the conventional gasoline vehicle exhibits higher values of the lifetime airpolluting emissions. As mentioned above, the gasoline vehicles show the lowest $\mathrm{NO}_{\mathrm{x}}$ and $\mathrm{PM}_{\mathrm{x}}$ emissions, but they indicate higher emissions of $\mathrm{CO}_{\mathrm{x}}$ and VOC than do the diesel vehicles. Figure 10 shows the percentage contribution of different life cycle stages.

It can be seen that the vehicle operation and use stage is the largest contributor to total air pollutant emissions during the lifetime of a vehicle, accounting for $62 \%-71 \%$ of total air pollutant emissions (Figure 10). The high percentage of air pollutant emission falls to production of a vehicle (production of parts and components, vehicle assembly). It is found that air-pollutants emitted during the vehicle production constitute $12 \%-16 \%$ of the total emissions of conventional vehicles, $17 \%$ of the total emissions of gasoline hybrid vehicles and $22 \%$ of the total emissions of diesel hybrid vehicles.

\section{Conclusion}

Typically, vehicle air pollutants emissions exhibit values during their operation. To estimate the average operation emissions, a number of driving cycles have been developed. These cycles reflect the vehicle driving conditions typical for a particular city, town, or region. The test cycles are used in vehicle approval tests to estimate carbon dioxide emissions and average fuel consumption. In the EU, the NEDC had been used to test passenger vehicles and light duty vehicles and it is now using the Worldwide Harmonized Light Vehicles Test Procedure, or WLTP for short. For buses, the International Association of Public Transport introduced the SORT cycles. However, standardized tests have a disadvantage. They do not fully reflect the real conditions of a vehicle operation. Therefore, in many works and projects are found the driving cycles developed for the traffic conditions of a particular city or region. Driving conditions have a significant influence on values for emissions and fuel consumption. Traffic conditions in the city are characterized by the low driving speeds, together with frequent acceleration, frequent braking and frequent stops. The non-urban driving conditions imply the higher speeds with less braking and fewer stops.

In order to assess the total emissions of a vehicle from production to end-of-life, the impact of the operation phase should be taken into account, as well as the emissions related to the manufacture of components, the assembly of a vehicle and production of fuel. The LCA method can be used for these purposes. It shows the influence of the different stages of the vehicle on the total emissions during the life of the vehicle. LCA can be used to make comparisons between the conventional and alternative vehicles and to facilitate purchasing decisions.

The paper shows the comparative life cycle analysis of conventional and hybrid drive vehicles with respect to various driving conditions. The presented results show that replacing a conventionally powered vehicle (diesel, gasoline) with a hybrid results in significant reduction of the lifetime air-pollutant emissions. In comparison to conventional cars, hybrids emitted $40 \%$ fewer air-pollutant lifetime emissions in urban driving condition, approximately $30 \%$ fewer life cycle airpollutant emissions in combined urban and non-urban area conditions and around $20 \%$ fewer air-pollutant lifetime emissions in driving conditions excluding the urban areas. The major vehicle contributor to total air pollutant emissions for vehicles lifetime is the operation and use stage.

\section{References}

[1] Greenhouse gas emission statistics - Eurostat [online] [accessed 2019-12-16]. Available from: https://appsso. eurostat.ec.europa.eu/nui/show.do?dataset=env_air_gge\&lang=en

[2] Emissions of air pollutants from transport - European Environment Agency (EEA) [online]. Available from: https://www.eea.europa.eu/data-and-maps/indicators/transport-emissions-of-air-pollutants-8/transportemissions-of-air-pollutants-8

[3] RODRIGUE, J. P. The geography of transport systems. 4. ed. Routledge, 2016. ISBN 1138669571.

[4] CHAPMAN, L. Transport and climate change: a review. Journal of Transport Geography [online]. 2007, 15(5), p. 354-367. ISSN 0966-6923. Available from: https://doi.org/10.1016/j.jtrangeo.2006.11.008

[5] SEILER, A., HELLDIN, J. O. Mortality in wildlife due to transportation. The Ecology of Transportation: Managing Mobility for the Environment [online]. 2006, 10, p. 165-189. ISBN 978-1-4020-4503-5. Available from: https://doi.org/10.1007/1-4020-4504-2_8

[6] RYTWINSKI, T., FAHRIG, L. The impacts of roads and traffic on terrestrial animal populations. In: Handbook of road ecology [online]. UK: John Wiley \& Sons Ltd, 2015. ISBN 9781118568187, eISBN 9781118568170, p. 237-246. Available from: https://doi.org/10.1002/9781118568170.ch28

[7] PARK, Y. S., LIM, S. H., EGILMEZ, G., SZMEREKOVSKY, J. Environmental efficiency assessment of U.S. transport sector: a slack-based data envelopment analysis approach. Transportation Research Part D: Transport 
and Environment [online]. 2018, 61, p. 152-164. ISSN 1361-9209. Available from: https://doi.org/10.1016/j. $\operatorname{trd} .2016 .09 .009$

[8] LUOMA, J., SIVAK, M. Interactions of environmental and safety measures for sustainable road transportation. European Transport Research Review [online]. 2012, 4(4), p. 189-199. ISSN 1867-0717. Available from: https:// doi.org/10.1007/s12544-012-0078-5

[9] SZUMSKA, E., JURECKI, R., PAWELCZYK, M. Evaluation of the use of hybrid electric powertrain system in urban traffic conditions. Eksploatacja i Niezawodnosc - Maintenance and Reliability [online]. 2020, 22(1), p. 154-160. Available from: http://ein.org.pl/sites/default/files/2020-01-18.pdf

[10] BHARADWAJ, S., BALLARE, S., ROHIT, CHANDEL, M. K. Impact of congestion on greenhouse gas emissions for road transport in Mumbai metropolitan region. Transportation Research Procedia [online]. 2017, 25, p. 3538-3551. ISSN 2352-1465. Available from: https://doi.org/10.1016/j.trpro.2017.05.282

[11] ZHANG, K., BATTERMAN, S., DION, F. Vehicle emissions in congestion: comparison of work zone, rush hour and free-flow conditions. Atmospheric Environment [online]. 2011, 45(11), p. 1929-1939. ISSN 1352-2310. Available from: https://doi.org/10.1016/j.atmosenv.2011.01.030

[12] KRZYZANOWSKI, M., KUNA-DIBBERT, B., SCHNEIDER, J. Health effects of transport-related air pollution [online]. World Health Organization, 2005. ISBN 9289013737. Available from: http://www.euro.who.int/en/ publications/abstracts/health-effects-of-transport-related-air-pollution

[13] Health risk assessment of air pollution. General principles [online]. World Health Organization, 2016. ISBN 9789289051316. Available from: http://www.euro.who.int/en/publications/abstracts/health-risk-assessmentof-air-pollution.-general-principles-2016

[14] BǍK, I., SZCZECINSKA, B., CHEBA, K. The impact of transport on the quality of the environment in cities of Poland - a statistical analysis. Transportation Research Procedia [online]. 2019, 39, p. 24-33. ISSN 2352-1465. Available from: https://doi.org/10.1016/j.trpro.2019.06.004

[15] FINKBEINER, M. Special types of life cycle assessment. Springer, 2016. ISBN 978-94-017-7610-3.

[16] DEL PERO, F., DELOGU, M., PIERINI, M. Life cycle assessment in the automotive sector: a comparative case study of internal combustion engine (ICE) and electric car. Procedia Structural Integrity [online]. 2018, 12, p. 521-537. ISSN 2452-3216. Available from: https://doi.org/10.1016/j.prostr.2018.11.066

[17] FOLEGA, P., BURCHART-KOROL, D. Environmental assessment of road transport in a passenger car using the life cycle approach. Transport Problems [online]. 2017, 12(2), p. 147-53. ISSN 1896-0596. Available from: https://www.exeley.com/transport_problems/doi/10.20858/tp.2017.12.2.14

[18] BICER Y., DINCER I., Life cycle environmental impact assessment and comparison of alternative fuel for clean vehicles. Resources, Conservation and Recycling [online]. 2018, 132, p. 141-157. ISSN 0921-3449. Available from: https://doi.org/10.1016/j.resconrec.2018.01.036

[19] KLIUCININKAS, L., MATULEVICIUS, J., MARTUZEVICIUS, D. The life cycle assessment of alternative chains for urban buses and trolleybuses. Journal of Environmental Management [online]. 2012, 99, p. 98-103. ISSN 0301-4797. Available from: https://doi.org/10.1016/j.jenvman.2012.01.012

[20] JWA, K., LIM, O. Comparative life cycle assessment lithium-ion battery electric bus and diesel bus from well-towheel. Energy Procedia [online]. 2018, 145, p. 223-227. ISSN 1876-6102. Available from: https://doi.org/10.1016/j. egypro.2018.04.039

[21] DAI, Q., KELLY, J.C., GAINES, L., WANG, M. Life cycle analysis of lithium-ion batteries for automotive applications. Batteries [online]. 2019, 5(2;48), p. 1-12. eISSN 2313-0105. Available from: https://doi.org/10.3390/ batteries5020048

[22] SOO, V. K., COMPSTON, P., DOOLAN, M. Interaction between new car design and recycling impact of life cycle assessment. Procedia CIRP [online]. 2015, 29, p. 426-431. ISSN 2212-8271. Available from: https://doi.org/10.1016/j.procir.2015.02.055

[23] SOO, V. K., PEETERS, J., COMPSTON, P., DOOLAN, M., DUFLOU, J. R. Comparative study of end-of-life vehicle recycling in Australia and Belgium, Procedia CIRP [online]. 2017, 61, p. 269-274. ISSN 2212-8271. Available from: https://doi.org/10.1016/j.procir.2016.11.222

[24] SZUMSKA, E., PAWELCZYK, M., PISTEK, V. Evaluation of the life cycle costs for urban buses equipped with conventional and hybrid drive trains. The Archives of Automotive Engineering - Archiwum Motoryzacji [online]. 2019, 83(1), p. 73-86. eISSN 2084-476X. Available from: https://doi.org/10.14669/AM.VOL83.ART5

[25] KARA, S., LI, W., SADJIVA, N. Life cycle cost analysis of electrical vehicles in Australia. Procedia CIRP [online]. 2017, 61, p. 767-772. ISSN 2212-8271. Available from: https://doi.org/10.1016/j.procir.2016.11.179

[26] GREET life-cycle model. User guide. Center for Transportation Research Energy Systems Division, Argonne National Laboratory, 2016. 